\title{
REVIEW
}

\section{Contents of cadmium and mercury in edible mushrooms}

\author{
Pavel Kalač, Lubomír Svoboda, Božena Havlíčková \\ Department of Chemistry, Faculty of Agriculture, University of South Bohemia, České Budějovice, Czech \\ Republic
}

Received $1^{\text {st }}$ October 2003.

Revised $23^{\text {rd }}$ October 2003.

Published online $30^{\text {th }}$ October 2003.

\begin{abstract}
Summary
Wild mushrooms are a popular delicacy in many countries and their consumption is rather high in some individuals. Some species, mainly from the genera Agaricus, Macrolepiota, Lepista and Calocybe accumulate a high content of cadmium and mercury even in unpolluted areas. Levels of these metals increase considerably in heavily polluted sites, such as in the vicinity of both working and abandoned metal smelters or inside cities. Current knowledge of the chemical forms of the metals bound in mushrooms is limited, as are data on their bioavailability in man. Consumption of the species which do accumulate these metals should thus be restricted. A low content of the metals in cultivated mushroom species is characteristic.
\end{abstract}

Keywords: heavy metals - cadmium - mercury - edible mushroom

\section{INTRODUCTION}

Mushrooms (higher fungi, macrofungi), both wild growing and cultivated, are a popular delicacy in many countries, with some people consuming several kilos per year, mainly in countries of Central and East Europe and the Far East. However, many mushroom species accumulate trace elements to a considerably higher extent than plants. About forty trace elements have been reported in the literature to date, with cadmium and mercury being the most important from the point of view of human health.

Existing research has had two main objectives. The first is to test the suitability of wild mushrooms as a bioindicator of environmental pollution by a number of heavy metals. Such an approach has been preferred in Western Europe, where the consumption of wild mushrooms has been very limited, culminated in the 1980's and attenuated after the observation that mushrooms cannot be used as a reliable indicator. The second objective is to search for edible species which accumulate high levels of harmful elements. This research has been carried out mainly in countries with a high consumption of wild mushrooms.

A number of reviews have been published of trace element content in mushrooms (Seeger 1982, Michelot et al. 1998, Kalač and Svoboda 2000). Moreover, many mushroom species accumulate high or very high levels of radioactive isotopes of caesium (reviewed by Kalač 2001). The literature dealing with potentially harmful cadmium and mercury content in edible mushrooms is reviewed in this article.

Several mycological terms are used within the article: the fruiting body is the visible, commonly aboveground part of a mushroom, fructification is the formation of the fruiting body. The fruiting body consists of a cap (pileus) with a spores- 
forming part (sporophore), and a stipe (stem or stalk). A mushroom uptakes nutrients from a substrate via specious mycelium.

\section{FACTORS AFFECTING THE METAL CONTENT IN FRUITING BODIES}

Knowledge about the physiological roles of cadmium and mercury in mushrooms is very limited. The content of both metals is primarily species-dependent, while the importance of the genus or family, age and size of the fruiting body is limited. The nutritional strategy, mycorrhizal, parasitic or saprophytic, seems to be of significance. A higher content of both cadmium (Melgar et al. 1998) and mercury (Alonso et al. 2000) was reported for saprophytic species as compared to mycorrhizal ones, however, exceptions occurred. Great differences exist in the uptake of individual metals from substrate to fruiting bodies (Tyler 1982, Gast et al. 1988). The ability to accumulate a metal is characterised by the bioaccumulation factor, the ratio of content in the fruiting body dry matter to the substrate dry matter. Both cadmium and mercury are strongly accumulated in many mushroom species. Factors 50-300 and 30-500 were reported for cadmium and mercury, respectively, while, for instance, only 0.01-0.1 for lead (Seeger 1982).

The proportion of the metal content originating from atmospheric depositions seems to be also of less importance. The lifetime of a fruiting body is short, usually only 10-14 days. In our opinion, the metal content in fruiting bodies is considerably affected by the age of the mycelium and the interval between fructifications. However, scientific evidence for such opinion is lacking. Nevertheless, maximum metal content has been observed in the initial harvest wave of the cultivated white mushroom (Agaricus bisporus). Metal levels reported in wild growing A. bisporus are considerably higher than those in cultivated fruiting bodies. The probable explanation is that it is not only due to different substrate composition and contamination, but also to the very different age of the mycelium, which may exist for several years in nature, while only for several months in a cultivation plant. Thus, cadmium and mercury contents are considerably lower in the cultivated mushrooms than in the same or taxonomicallyrelated wild species (Haldimann et al. 1995).

The combination of all these factors causes a very wide variability of metal content within a species, commonly to one order of magnitude. Thus, ranges of the metal levels are remarkably broader than in plant materials. The metals are distributed unevenly within a fruiting body. The highest content has been observed in the sporeforming part, but not in the spores; lower content in the rest of the cap and the lowest level in the stipe (Thomet et al. 1999).

The surprising ability of some mushroom species to accumulate promoted their testing as bioindicators for the metals. As reviewed by Wondratschek and Röder (1993), no mushroom species could be considered as a reliable indicator of environmental pollution with heavy metals. However, cadmium and mercury contents in fruiting bodies increase in polluted areas. High metal levels have been observed in mushrooms growing in heavily contaminated areas, such as those in the close vicinity of highways with heavy traffic (Cuny et al. 2001), emission areas (Lepšová and Mejstř́ik 1988), and inner cities (Kuusi et al. 1981, Svoboda and Kalač 2003). Extremely high metal contents have been reported from the vicinity of metal smelters (Liukkonen-Lilja et al. 1986, Kalač et al. 1991, 1996, Svoboda et al. 2000, Collin-Hansen et al., 2002). A high metal content was reported also from areas contaminated historically by ore mining and processing (Bargagli and Baldi 1984, Fischer et al. 1995).

Metal content has usually been expressed in $\mathrm{mg} / \mathrm{kg}$ dry matter. There is a consensus for recalculation to fresh matter that mushrooms have dry matter content $10 \%$. For intake calculations, usually $300 \mathrm{~g}$ of fresh mushrooms per meal is assumed.

\section{HEALTH ASPECTS}

Extensive information is available on the metal content in many mushroom species. Literature data for 25 species, commonly consumed from unpolluted areas in Central Europe, were tabulated in our previous review (Kalač and Svoboda 2000). However, a plausible assessment of the health risk from mushroom consumption has been difficult due to very limited knowledge on the chemical form of the metals (speciation) and their bioavailability in man.

Some countries have established statutory limits for the metals in edible mushrooms. For instance, current Czech regulations list 66 wild growing and 15 cultivated marketable species with limits of 2.0 and $5.0 \mathrm{mg} / \mathrm{kg}$ dry matter for cadmium and mercury, respectively in wild growing mushrooms, and $1.0 \mathrm{mg} / \mathrm{kg}$ dry matter for mercury in cultivated species. According to $\mathrm{FAO} / \mathrm{WHO}$ recommendations, acceptable weekly intakes are 0.007 and $0.005 \mathrm{mg}$ per kg body weight for cadmium and mercury, respectively. 


\section{Cadmium}

Cadmium levels in most edible species growing in unpolluted (background) areas are below $2 \mathrm{mg} / \mathrm{kg}$ dry matter. However, the content in Boletus aestivalis, Leccinum scabrum, Calocybe gambosa, Armillaria mellea and Russula cyanoxantha can be up to $5 \mathrm{mg} / \mathrm{kg}$ dry matter (Kalač and Svoboda 2000) and in the genus Agaricus up to $50 \mathrm{mg} / \mathrm{kg}$ dry matter, mainly in species yellowing after tissue mechanical damage (Table 1). An extremely high content of up to $300 \mathrm{mg} / \mathrm{kg}$ dry matter has been reported (Schmitt and Meisch 1985). Such levels should be expected mainly in fruiting bodies of accumulating species growing in the close vicinity of metal smelters or within towns.

Information on the chemical forms of cadmium in mushrooms is very limited. Macrofungi have several tolerance mechanisms against toxicity of cadmium (Gadd 1993). Intracellular detoxification accomplished by cadmium and other metals binding to proteins probably has an important role. Such fungal proteins include metallothioneines containing cysteine, reported in A. bisporus with ability to bind copper (Münger and Lerch, 1985) and cadmium-mycophosphatin (Meisch and Schmitt 1986). The latter compound isolated from A. macrosporus is a phosphoglycoprotein of molecular weight $12 \mathrm{kDa}$ lacking cysteine, with a high proportion of acidic amino acids, glucose and galactose. Moreover, four low-molecular glycoproteins containing sulphur and binding cadmium were isolated simultaneously. No metallothioneines were found in fruiting bodies of cultivated A. bisporus (Esser and Brunnert 1986) or in Boletus edulis (Collin-Hansen et al. 2003). Two other essential cadmium-detoxification mechanisms were observed in the inedible mycorrhizal mushroom Paxillus involutus - cadmium bound onto cell walls and accumulated in the vacuolar compartments (Blaudez et al., 2000).

The initial information (Schellmann et al. 1980, Diehl and Schlemmer, 1984) on cadmium bioavailability from mushrooms reported a low proportion, only up to $10 \%$. However, further work observed a comparable and higher absorption from mushrooms than from inorganic cadmium salts (Seeger et al. 1986, Lind et al. 1995, Mitra et al. 1995). Cadmium is accumulated mainly in the kidneys, spleen and liver and its level in blood serum increases considerably following mushroom consumption. Thus, cadmium seems to be the most deleterious among heavy metals in mushrooms. Its acceptable daily or weekly intake may be easily reached by consumption of an accumulating mushroom species.

Table 1. Ranges of cadmium content in mushroom species accumulating above $5 \mathbf{~ m g} / \mathbf{k g}$ dry matter in unpolluted sites (adapted from Kalač and Svoboda 2000)

$\begin{array}{lc}\text { Agaricus campestris } & 5-50 \\ \text { Agaricus arvensis } & 5-20 \\ \text { Agaricus silvaticus } & 5-50 \\ \text { Agaricus silvicola } & 10->50\end{array}$

\section{Mercury}

Heavily accumulating species with up to $20 \mathrm{mg} / \mathrm{kg}$ dry matter of mercury in unpolluted areas are Calocybe gambosa, Lepista nuda and Agaricus arvensis. High contents up to $10 \mathrm{mg} / \mathrm{kg}$ dry matter are typical for the genera Agaricus and Macrolepiota (Table 2) and levels up to $5 \mathrm{mg} / \mathrm{kg}$ dry matter for the genus Boletus (Kalač and Svoboda 2000). An extremely high content, one order of magnitude higher than the levels from unpolluted areas, was observed in sites polluted from both historical and/or present mercury smelters
(Fischer et al. 1995, Kalač et al. 1996, Svoboda et al. 2000). A similar situation was reported in the vicinity of a chemical plant using mercury as an electrode in the production of sodium hydroxide from common salt (Lodenius and Herranen 1981). Thus, a content up to $200 \mathrm{mg} / \mathrm{kg}$ dry matter was determined.

Interesting information on the distribution of mercury in cap and stipe and on the values of the bioaccumulation factor between mercury content and underlying substrate from depth $0-10 \mathrm{~cm}$ for numerous species was reported by Falandysz et al. (2003 a,b,c). Surprisingly high bioaccumulation 
factor levels of 960 and 310 were found for cap and stipe, respectively, of Calvatia excipuliformis (Falandysz et al. 2003a).

Unfortunately, information on the chemical forms of mercury in mushrooms has been very scarce. Lasota and Florczak (1991) observed in cultivated $A$. bisporus most mercury bound in high-molecular weight proteins, while in cultivated Pleurotus ostreatus in protein fraction $17-45 \mathrm{kDa}$.
Limited data are also available on the proportion of highly toxic methylmercury $\mathrm{CH}_{3} \mathrm{Hg}^{+}$. This was reported to be usually only a few per cent, rarely up to $16 \%$ of total mercury (Stijve and Besson 1976, Bargagli and Baldi 1984, Kojo and Lodenius 1989, Fischer et al. 1995). Mushrooms accumulate methylmercury from a substrate with a bioaccumulation factor of about 20. Moreover, they are likely able to methylate inorganic mercuric salts (Fischer et al. 1995).

Table 2. Ranges of mercury content in mushroom species accumulating above $5 \mathbf{~ m g} / \mathbf{k g}$ dry matter in unpolluted sites (adapted from Kalač and Svoboda 2000)

$\begin{array}{lr}\text { Agaricus campestris } & 1-10 \\ \text { Agaricus arvensis } & 2-20 \\ \text { Macrolepiota rhacodes } & 2-10 \\ \text { Macrolepiota procera } & 1-10 \\ \text { Lepista nuda } & 2-20 \\ \text { Calocybe gambosa } & 5-20\end{array}$

\section{EFFECTS OF MUSHROOM PRESERVATION AND COOKING}

Only a few data are available on the decrease of cadmium and mercury content during different mushroom preservation and culinary treatments. Washing and peeling of $A$. bisporus lowered cadmium content by about 30-40\% (Źródlowski 1995). Mercury loss of about one third was observed during mushroom thermal treatment under high temperature, simulating e.g. pan-frying (Cibulka et al. 1999). Svoboda et al. 2002 investigated the leaching of cadmium and mercury from fresh, freeze-dried, air-dried and frozen slices of the widely consumed Xerocomus badius. Treatments were tested: soaking in $0.3 \%$ table salt solution at ambient temperature for 5,10 or $15 \mathrm{~min}$ or repeatedly for $3 \times 15 \mathrm{~min}$, or boiling in the same solution for 15,30 or $60 \mathrm{~min}$. Short-time boiling was observed to be a more efficient treatment than soaking. The metals were leached to the greatest extent from the most destroyed tissues of frozen slices. The lowest decrease was in fresh or freezedried mushrooms. Cadmium was leached to a higher extent than mercury.

\section{CONCLUSION}

While comprehensive literature has been available on the content of cadmium and mercury in many mushroom species from both unpolluted and differentially polluted areas, only very limited data deal with factors affecting their potential risk in human nutrition. Knowledge of chemical forms of the bound metals and their bioavailability in man has been scrappy. Thus, a critical, plausible assessment of the health risk from mushroom consumption has not been as yet possible and the consumption of both the accumulating species even from unpolluted areas and non-accumulating species from polluted sites should be restricted.

\section{ACKNOWLEDGEMENTS}

The authors thank the Grant Agency of the Czech Republic for the financial support by the grant 525/03/D067. 


\section{REFERENCES}

Alonso J., M.J. Salgado, M.A. García and M.J. Melgar: Accumulation of mercury in edible macrofungi: influence of some factors. Arch. Environ. Contam. Toxicol. 38: 158-162, 2000.

Bargagli R. and F. Baldi: Mercury and methyl mercury in higher fungi and their relation with the substrata in a cinnabar mining area. Chemosphere 13: 1059-1071, 1984.

Blaudez D., B. Botton and M. Chalot: Cadmium uptake and subcellular compartmentation in the ectomycorrhizal fungus Paxillus involutus. Microbiology 146: 1109-1117, 2000.

Cibulka J., E. Čurdová, D. Miholová and I. Stěhulová: Mercury loss from edible mushrooms after their model thermal treatment. Czech J. Food Sci. 17: 238-240, 1999.

Collin-Hansen C., K.E. Yttri, R.A. Andersen, B.O. Berthelsen and E. Steinnes: Mushrooms from two metal-contaminated areas in Norway: occurrence of metals and metallothionein-like proteins. Geochem.: Explor., Environ., Anal. 2: 121-130, 2002.

Collin-Hansen C., R.A. Andersen and E. Steinnes: Isolation and $\mathrm{N}$-terminal sequencing of a novel cadmium-binding protein from Boletus edulis. J. Phys. IV France 107: 311-314, 2003.

Cuny D., C. wan Haluwyn and R. Pesch: Biomonitoring of trace elements in air and soil compartments along the major motorway in France. Water Air Soil Pollut. 125: 273-289, 2001.

Diehl J.F. and U. Schlemmer: [Assessment of bioavailability of cadmium in mushrooms by means of feeding experiments with rats relevance for man]. Z. Ernährungswiss. 23: 126135, 1984 (in German).

Esser J. and H. Brunnert: Isolation and partial purification of cadmium-binding components from fruiting bodies of Agaricus bisporus. Environ. Pollut. A41: 263-275, 1986.

Falandysz J., M. Gucia, A. Brzostowski, M. Kawano, L. Bielawski, A. Frankowska and B. Wyrzykowska: Content and bioconcentration of mercury in mushrooms from northern Poland. Food Addit. Contam. 20: 247-253, 2003a.

Falandysz J., M. Kawano, A. Świeczkowski, A. Brzostowski and M. Dadej: Total mercury in wild-grown higher mushrooms and underlying soil from Wdzydze Landscape Park, Northern Poland. Food Chem. 81: 21-26, 2003 b.

Falandysz J., K. Lipka, M. Kawano, A. Brzostowski, M. Dadej, A. Jędrusiak and T. Puzyn: Mercury content and its bioconcentration factors in wild mushrooms at Lukta and Morag, Northeastern Poland. J. Agric. Food Chem. 51: 2832-2836, 2003c.
Fischer R.G., S. Rapsomanikis, M.O. Andreae and F. Baldi: Bioaccumulation of methylmercury and transformation of inorganic mercury by macrofungi. Environ. Sci. Technol. 26: 993-999, 1995.

Gadd G.M.: Interactions of fungi with toxic metals. New Phytol. 124: 25-60, 1993.

Gast C.H., E. Jansen, J. Bierling and L. Haanstra: Heavy metals in mushrooms and their relationship with soil characteristics. Chemosphere 17: 789-799, 1988.

Haldiman M., C. Bajo, T. Haller, T. Venner and B. Zimmerli: [Contents of arsenic, lead, cadmium, mercury and selenium in cultivated mushrooms]. Mitteil. Gebiete Lebensmittelunters. Hyg. 86: 463-484, 1995 (in German).

Kalač P.: A review of edible mushroom radioactivity. Food Chem. 75: 29-35, 2001.

Kalač P. and L. Svoboda: A review of trace element concentrations in edible mushrooms. Food Chem. 69: 273-281, 2000.

Kalač P., J. Burda and I. Stašková: Concentrations of lead, cadmium, mercury and copper in mushrooms in the vicinity of a lead smelter. Sci. Total Environ. 105: 109-119, 1991.

Kalač P., M. Nižnanská, D. Bevilaqua and I. Stašková: Concentrations of mercury, copper, cadmium and lead in fruiting bodies of edible mushrooms in the vicinity of a mercury smelter and a copper smelter. Sci. Total Environ. 177: 251-258, 1996.

Kojo M.R. and M. Lodenius: Cadmium and mercury in macrofungi - mechanisms of transport and accumulation. Angew. Bot. 63: 279-292, 1989.

Kuusi T., K. Laaksovirta, H. Liukkonen-Lilja, M. Lodenius and S. Piepponen: Lead, cadmium, and mercury contents of fungi in the Helsinki area and in unpolluted control areas. Z. Lebensm. Unters. Forsch. 173: 261-267, 1981.

Lasota W. and J. Florczak: [Effects of growing conditions on accumulation of some toxic substances in mushrooms. II. Absorption and binding of ${ }^{203} \mathrm{Hg}$ by Agaricus bisporus Lange and Pleurotus ostreatus Jacq. Fr. Kumm.]. Bromatol. Chem. Toksykol. 24:67-71, 1991 (in Polish).

Lepšová A. and V. Mejstřík: Accumulation of trace elements in the fruiting bodies of macrofungi in Krušné Hory Mountains, Czechoslovakia. Sci. Total Environ. 76: 117-128, 1988.

Lind Y., A.W. Glynn, J. Engman and L. Jorhem: Bioavailability of cadmium from crab hepatopancreas and mushrooms in relation to inorganic cadmium: a 9-week feeding study in mice. Food Chem. Toxicol. 33: 667-673, 1995.

Liukkonen-Lilja, H., T. Kuusi, K. Laaksovirta, M. Lodenius and S. Piepponen: The effect of lead 
processing works on the lead, cadmium and mercury contents of fungi. Z. Lebensm. Unters. Forsch. 176: 120-123, 1986.

Lodenius M. and M. Herranem: Influence of a chlor-alkali plant on the mercury content in fungi. Chemosphere, 10: 313-318, 1981.

Meisch H.-U. and J.A. Schmitt: Characterization studies on cadmium-mycophosphatin from the mushroom Agaricus macrosporus. Environ. Health Persp. 65: 29-32, 1986.

Melgar M.J., J. Alonso, M. Pérez-López and M.A. Garcia: Influence of some factors in toxicity and accumulation of cadmium from edible wild macrofungi in NW Spain. J. Environ. Sci. Health B33: 439-455, 1998.

Michelot D., E. Siobud, J.C. Dore, C. Viel and F. Poirier: Update of metal content profiles in mushrooms - toxicological implications and tentative approach to the mechanisms of bioaccumulation. Toxicon 36: 1197-2012, 1998.

Mitra A.K., R.P. Purkayastha, N.B. Chatterjee and B. Bhattacharyya: Uptake and tissue distribution of cadmium in albino rat after oral exposure to cadmium-contaminated edible mushroom and its effect on blood. Curr. Sci. 68: 1050-1053, 1995.

Münger K. and K. Lerch: Copper metallothionein from the fungus Agaricus bisporus - chemical and spectroscopic properties. Biochemistry 24: 6751-6756, 1985.

Schellmann B., M.-J. Hilz and O. Opitz: [Fecal excretion of cadmium and copper after Agaricus mushroom diet]. Z. Lebensm. Unters. Forsch. 171: 189-192, 1980 (in German).

Schmitt J.A. and H.-U. Meisch: Cadmium in mushrooms - distribution, growth effect and binding. Trace Elem. Med. 2: 163-166, 1985.

Seeger R.: [Toxic heavy metals in mushrooms]. Dtsch. Apoth. Z. 122: 1835-1844, 1982 (in German).
Seeger R., F. Schiefelbein, R. Seuffert and W. Zant: Absorption of cadmium ingested with mushrooms. Naunyn-Schmiedeberg's Arch. Pharmacol., 332: Suppl. 110, 1986.

Stijve T. and R. Besson: Mercury, cadmium, lead and selenium content in mushroom species belonging to the genus Agaricus. Chemosphere 5: 151-158, 1976.

Svoboda L. and P. Kalač: Contamination of two edible Agaricus spp. mushrooms growing in a town with cadmium, lead, and mercury. Bull. Environ. Contam. Toxicol., 71: 123-130, 2003.

Svoboda L., K. Zimmermannová and P. Kalač: Concentrations of mercury, cadmium, lead and copper in fruiting bodies of edible mushrooms in an emission area of a copper smelter and a mercury smelter. Sci. Total Environ. 246: 6167, 2000.

Svoboda L., P. Kalač, J. Špička and D. Janoušková: Leaching of cadmium, lead and mercury from fresh and differently preserved edible mushroom, Xerocomus badius, during soaking and boiling. Food Chem. 79: 41-45, 2002.

Thomet U., E. Vogel and U. Krähenbühl: The uptake of cadmium and zinc by mycelia and their accumulation in mycelia and fruiting bodies of edible mushrooms. Eur. Food Res. Technol. 209: 317-324, 1999.

Tyler G.: Accumulation and exclusion of metals in Collybia peronata and Amanita rubescens. Transact. Br. Mycol. Soc. 79: 239-245, 1982.

Wondratschek I. and U. Röder: Monitoring of heavy metals by higher fungi. In: Markert B. (Ed.): Plants as biomonitors. Indicators for heavy metals in the terrestrial environment. Weinheim, VCH, 1993, pp. 345-363.

Źródlowski Z.: The influence of washing and peeling of mushrooms Agaricus bisporus on the level of heavy metal contaminants. Pol. J. Food Nutr. Sci., 45: 26-33, 1995.

\section{Address:}

Pavel Kalač, University of South Bohemia, Faculty of Agriculture, Department of Chemistry, Branišovská 31, 37005 České Budějovice, Czech Republic; kalac@zf.jcu.cz 